
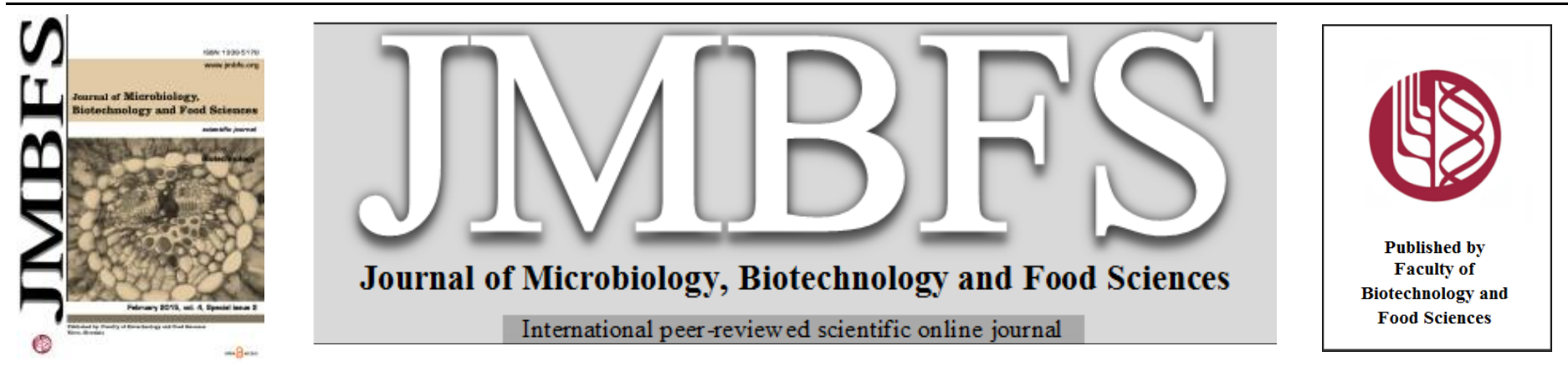

\title{
THE DIFFERENCES BETWEEN THE OLD AND NEW BARLEY VARIETIES ON THE BASIS OF HORDEIN POLYMORPHISM WITH RESPECT TO QUALITATIVE PARAMETERS
}

\section{Marián Tomka*, Milan, Chňapek, Zdenka Gálová, Dana Urminská}

Address(es): Marián Tomka,

Slovak University of Agriculture in Nitra, Faculty of Biotechnology and Food Sciences, Department of Biochemistry and Biotechnology, Trieda A. Hlinku 2, 94976 Nitra, Slovak republic, +421 376414277 .

*Corresponding author: ing.mariantomka@gmail.com

doi: 10.15414/jmbfs.2015.4.special2.108-110

\section{ARTICLE INFO}

Received 14.11.2014

Revised 23. 12. 2014

Accepted 14. 1.2015

Published 2. 2. 2015

Short communication

open $\partial$ access

\section{ABSTRACT}

The current registered barley varieties are classified according to their biological and economic characters meeting the growing conditions. Varieties are characterized using molecular markers on the level of protein and DNA. Using starch gel electrophoresis we studied the frequency of hordein alleles, which are potential markers of economically important traits of 30 barley varieties. Among the 26 alleles detected in two main loci (Hrd A, Hrd B), we identified 7 potential markers (A3, A12, A23, B8, B17, B19, B47) with the frequency ranged from $1.18 \%$ to $12.14 \%$. Number of these alleles differs over the years and together with number of lines per variety has decreasing tendency. On the basis of the detected alleles we are able to predict malting quality parameters and resistance to most common barley pathogens.

Keywords: Barley, hordeins, polymorphism, protein markers

\section{INTRODUCTION}

Genebanks all around the world collected 486,724 barley accessions and this collection is second largest after wheat (FAO, 1996). In the basic collection of Gene bank of Slovak republic which includes only domestic accessions, there are 21 accessions (Benková, 2005). Barley genotypes in recent years undergone significant changes mainly due to breeding aimed at improving the qualitative and quantitative parameters. High malting varieties are required by breweries and distilling industry. Barley breeding programmes have been oriented to individual agro-ecological regions combining good adaptability, yield stability and end-use quality Ovesná et al. (2004). Starch gel electrophoresis is used very often for fast screening analysis of protein mixtures (Kephart, 1990). Markering effects of barley protein signal genes can be determined by the approximate determination of constant occurrence of individual allelic blocks of signal genes and individual markered characters Černý et al. (1999). Varieties whose genealogical ancestors were regional populations of hanacky barley served as malting quality standards for new barley varieties in central Europe (Lekeš, 1997). Some subunits are closely linked to agricultural characteristics and quality of malt. Based on the detected profile of hordein subunits Lee et al., (2010) confirmed the relationship between subunits of molecular weight 38, 43 and $65 \mathrm{kDa}$ and lines with high malt quality. Hordein polymorphism can help the breeder obtain useful information about variability of the crude protein content of genotype already in the early stage of breeding process when amount of grain is not sufficient for deep evaluation of grain quality Bleidere and Grunte (2009). The current requirements on the quality of the malting barley prefer only varieties with a strong enzymatic activity and high content of extract (Kosař et al., 2004).

The objective of our study was to evaluate the presence of protein markers through different years.

\section{MATERIAL AND METHODS}

We have analyzed 30 genotypes of barley from a Gene Bank of Slovak Republic, Research Institute of Plant Production in Pieštany SARC, central and testing Institute in agriculture in Bratislava (ÚKSUP), Gene Bank of seed species of Czech Republic and AGRO BSS s.r.o. Sládkovičovo. Most genotypes had Slovak origin (table 1).

Table 1 Characteristics of analyzed barley genotypes

\begin{tabular}{llllllll}
\hline Variety & Form & Origin & Y.R. & Variety & Form & Origin & Y.R. \\
\hline Adran & spring & SVK & 2004 & SK 4451 & spring & SVK & 1999 \\
\hline Amos & spring & SVK & 1995 & SK 5104 & spring & SVK & - \\
\hline Diosecký kneifl & spring & CSR & 1938 & SK 5374 & spring & SVK & - \\
\hline Expres & spring & SVK & 1999 & SK 5451 & spring & SVK & - \\
\hline Garant & spring & SVK & 1994 & SK 5526 & spring & SVK & 2007 \\
\hline Jubilant & spring & CSFR & 1991 & SK 5835 & spring & SVK & 2006 \\
\hline Kosan & spring & SVK & 1994 & SK 5840 & spring & SVK & 2006 \\
\hline Ludan & spring & SVK & 2002 & Slaven & spring & SVK & 2007 \\
\hline Nadir & spring & SVK & 2006 & Slovenský kvalitný & spring & CSR & 1946 \\
\hline Nitran & spring & SVK & 2003 & Stabil & spring & SVK & 1993 \\
\hline Orbit & spring & CSSR & 1986 & Tatry 1995-196 & spring & SVK & 1996 \\
\hline Poprad & spring & SVK & 2006 & Terrasol pivovarský & spring & CSR & 1944 \\
\hline Pribina & spring & SVK & 2005 & Tiffany & winter & GER & 1996 \\
\hline Progres & spring & SVK & 1998 & Vladan & spring & SVK & 1996 \\
\hline SK 13-9-91 & spring & SVK & 1996 & Zlatan & spring & SVK & 1994 \\
\hline
\end{tabular}

Legend: Y.R. - year of registration, SVK - Slovakia, CSFR - Czechoslovakia (1990-1992), CSSR - Czechoslovakia (1960-1989),

CSR - Czechoslovakia (1918-1960), GER - Germany 
Storage proteins were isolated from the endosperm of whole, dry, mature grains according to optimized ČSN 46 1085-1 (Bradová, Sýkorová, 2006). Grains (48 from each variety) were mechanically homogenized and put into an Eppendorf tube, wherein the extraction of hordeins took place in $65 \%$ ethanol.

Electrophoresis, fixation and staining of starch gels were performed under optimized ČSN 46 1085-1 (Bradová, Sýkorová, 2006). Nigrosin dyeing solution was used to detect hordeins in starch gels and after dyeing, gels were evaluated and photographed. Evaluation of the gels and identification of alleles was carried out by comparing gels with collection of standards from Crop research Institute in Prague and catalogues published by Pomortsev et al., $(2007,2008,2010)$.

\section{RESULTS AND DISCUSSION}

In the analyzed group of barley genotypes using electrophoretic separation of hordeins on starch gel electrophoresis we detected a total of 85 lines and 49 different hordein profiles. We have evaluated the number of lines per variety and presence of different hordein alleles in the barley varieties, which were registered between the years 1938 and 2007. During these years, hordein composition of varieties losses its diversity as we can see on figure 1 , where average number of alleles is decreasing. Loss of allelic diversity is also reflected in the reduction of intravarietal polymorphism represented by decrease in the number of lines per variety. Newer genotypes of barley were more homogenous than older what is caused by intensive breeding during last years. This breeding eliminates some hordein alleles, which can be found in older regional varieties, and these alleles can be important as markers of barley quality.

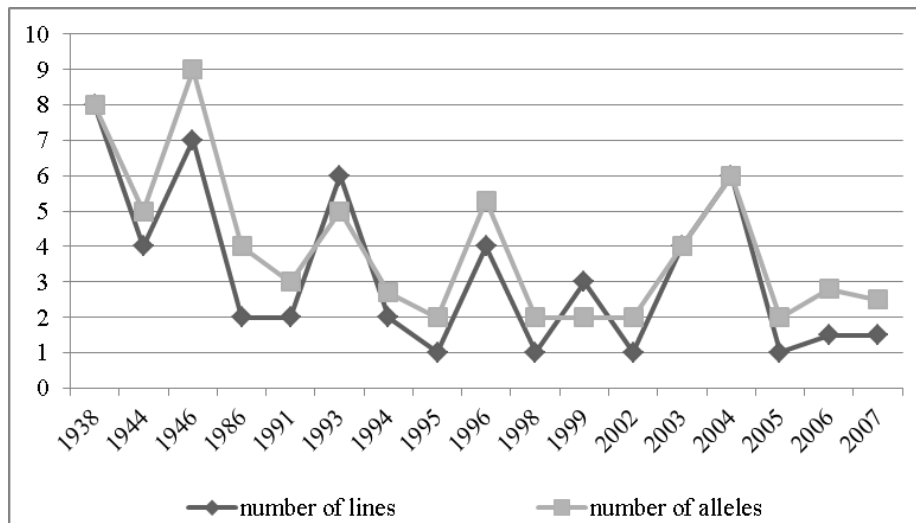

Figure 1 Average number of lines and alleles in barley varieties according to year of registration

Content of extract in the malt dry matter is the one of the main indicator of malting quality. Values over $80 \%$ are considered as optimal for this parameter and current genotypes have this value about $83 \%$. Černý et al. (1999) proved relation between allele B47 occurrence and this parameter. As we can see on figure 3, this allele have been detected more often in the newer genotypes (Progres, Pribina, SK 5526) and that confirms the tendency of breeding varieties with higher malting quality in the last years. On the other hand allele B8 that is potential marker of lower values of content of extract was detected only in one older variety (Slovensky kvalitny). Hordein allele B47 (frequency 14.12\%) is one of the alleles that are responsible for high portion of grain above the $2.5 \mathrm{~mm}$ sieve, what is one of the important parameter of technological quality of seed. Bigger seeds contain more starch and are linked with greater content of extract.

Černý et al. (1999) found strong dependence between the genes for thousand seeds weight and occurrence of hordein allele A23. This parameter is one of the main yield elements of cereals and it is also an indicator of technological quality of grain. Allele A23 (frequency 10.59\%) occurs mainly in the varieties from last years (Adran, SK 5835, SK 5840, Slaven) but we have detected this allele also in varieties registered in 1991 (Jubilant) and 1996 (Tatry 1995-196) what is in accordance with findings of similar research of Benková and Žáková (2007)

Malting quality of barley genotypes is affected not only by the genotypic but also by environmental factors. One of the most studied factors is resistance of barley to its pathogens such as Pucinia hordeii causing leaf rust and Blumeria gramini f. sp. hordei causing barley powdery mildew. On the basis of detected hordein allele A12 (frequency 14.12\%) we are able to identify genotypes (SK 4451) with higher resistance to barley powdery mildew becauce this allele is markering genes controlling the resistance to this disease Černý et al. (1999). On the other side is allele B17, which indicates susceptibility to powdery mildew, which reduces the photosynthetic performance of plants and pumped away water and nutrients. Also hordein alleles B8 (frequency 1.18\%) and B19 (frequency $14.12 \%$ ) are significantly markers of the susceptibility to leaf rust on barley, which causes direct losses of yield. The only reliable and effective prevention is the use of resistant varieties of barley which can be identified by detecting the hordein allele B52. In our collection we have not detected the presence of this allele.
Hordein allele A3 occurs only in 1 analyzed winter barley variety (Tiffany) with $2.23 \%$ frequency. Černý et al. (1999) also detected this allele only in winter barley and therefore it can be used as marker for winterhariness but another analysis with more winter barleys are needed.

In general we may say, that "negative" alleles such as B8 or B17 were detected in a few barley genotypes and after years of breeding they are not as frequent in new varieties as in older barley varieties.

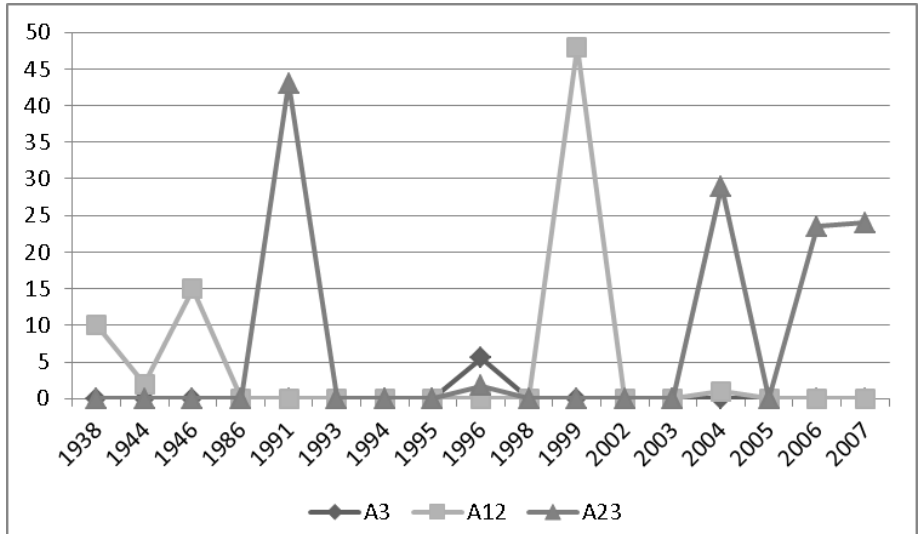

Figure 2 Average number of monitored hordein alleles in HrdA locus $(48=$ $100 \%$ ) during years 1938 to 2007

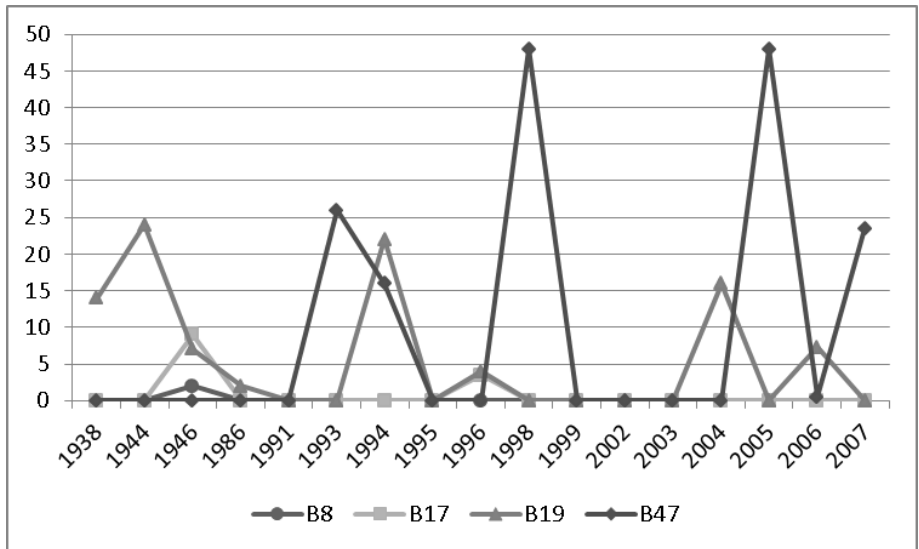

Figure 3 Average number of monitored hordein alleles in HrdB locus $(48=$ $100 \%$ ) during years 1938 to 2007

\section{CONCLUSION}

Older varieties of barley from our collection are characterized by greater variability than new varieties according to number of detected lines and significant decrease of allele diversity trough many years. But these older, mainly regional varieties, can be used as an important source of alleles for further breeding programs. According to detected alleles we can predict the quality of barley seed and determine the direction of its further end use. Based on the identification of certain alleles (B47) we are able to determine genotypes suitable for the brewing industry.

Acknowledgments: The work was financially supported with project VEGA 1/0471/09 and KEGA024SPU-4/2013.

\section{REFERENCES}

BENKOVÁ, M. 2005. Solution of barley collection . In Genofond (information rapporteur), 9,34

BENKOVÁ, M. - ŽÁKOVÁ, M. 2007. The quality of old and new malting barley. New knowledge of the genetics and breeding of agricultural products (Proceedings of the 14th Scientific Conference), 2007, Pieštany : VÚRV, $100-$ 102.

BLEIDERE, M. - GRUNTE, I. 2009. Hordein Diversity in Spring Barley Genotypes Related to Crude Protein Content. In LLU Raksti, 22, 2009, 89-99. BRADOVÁ, J. - SÝKOROVÁ, S. 2006. Optimalization of electrophoresis methods for protein identifying of barley varieties (Hordeum vulgare L.). Prague : VÚRV, 2006, 36p. ISBN: 80-86555-97-6.

ČERNÝ, J., ŠAŠEK, A., LANGER, I., BRADOVÁ, J., PAŘÍZEK, P., VEJL, P. VOPRŠAL, J. 1999. Markering of some barley traits by means of hordein signal genes. In Scientia Agriculturae Bohemica, 30, 1999, 185-207.

FAOSTAT. 2004 
KEPHART, S. R. 1990. Strach gel electrophoresis of plant isozymes: a comparative analysis of techniques. In American Journal of Botany, 77, 1990 693-712.

KOSA ̌̌, K. - PSOTA, V. - MIKYŠKA, A. 2004. Barley varieties suitable for the production of czech type beer. 9-th International Barley Genetics Symposium, Brno : Agricultural Research Institute Kromeriz, 167-169.

LEE, Y. J. - LEE, T. G. - JEON, W. B. - KIM, D. Y. - HONG, M. J. - LEE, M

B. - HYUN, J. N. - KIM, M. J. - LEE, M. J. - PARK, CH. S. - SEO, Y. W.

2010. Employment of Hordein Subunit Polymorphism in Establishing Selection Criteria for High Quality Malting Barley (Hordeum vulgare, L.). In Journal of crop science and biotechnology, 13(2), 91 - 97.

LEKEŠ, J. 1997. Cereal breeding in Czechoslovakia. 1997, Prague : Brázda, p. 80. ISBN 80-209-0271-6.

OVESNÁ, J., KUČERA, K., POLÁKOVÁ, K., VACUlOVÁ, K., MILOTOVÁ, J. 2004. Assessment of Diversity of Czech Barley Cultivars as Revealed by PCR Markers, SSR, AFLP and DNA Assays. 9-th International Barley Genetics Symposium, Brno : Agricultural Research Institute Kromeriz, p.39-48.

POMORTSEV, A. A. - LYALINA, E.V. 2007. Polymorphism of the cultivated barley (Hordeum vulgare, L.) of South Arabia at hordein-coding loci. In Russian Journal of Genetics, 43(5), p. 536 - 543.

POMORTSEV, A.A. - MARTYNOV, S.P. - LIALINA, E.V. 2008. Hordein locus polymorphism in near eastern local populations of cultivated barley (Hordeum vulgare L.) In Russian Journal of Genetics, 44(6), 815-828.

POMORTSEV, A. A. - MARTYNOV, S.P. - KOVALEVA, O. N. - LIALINA, E.V. 2010. Polymorphism of Hordein-Coding Loci in Cultivated Barley (Hordeum vulgare L.) in Afghanistan. In Russian Journal of Genetics, 46(11) $1327-1334$ 